\title{
Conflict-of-Interests Statutes and the Need for a Demand on Directors in Derivative Actions
}

\author{
Richard M. Buxbaum $\dagger$
}

Where there is no complainant there is no judge. ${ }^{1}$ Nowhere is the substantive law so dependent upon the availability of a person entitled to complain of its breach as im the case of hitigation on behalf of a corporation. It is a statutory truisin that the affairs of a corporation are managed by its board of directors, ${ }^{2}$ and this includes litigation. ${ }^{3}$ If, however, the directors will not initiate corporate litigation, and if this refusal is dispositive, then whatever harm allegedly was done to the corporation goes unredressed. To reinedy this situation a procedure known as the derivative suit is utilized. Its role in triggering corporate litigation against third parties is iniportant, but even inore important is its role $\mathrm{m}$ triggering suits against those corporate insiders, particularly directors, who by their imprudent or disloyal behavior nay have damaged the corporation. ${ }^{4}$

Current developinents concerning the prerequisites to allowing a volunteer shareholder to sue on belialf of the corporation are the focus of this Article; in particular, I will examine the so-called demand on directors ${ }^{5}$ as a condition precedent to such derivative actions. ${ }^{6}$

It is the thesis of this Article that many recent cases holding that a prior dennand on directors was required, or, if made and rejected, dis-

$\dagger$ Professor of Law, Boalt Hall, University of California, Berkeley. A.B. 1950, LL.B. 1952, Cornell University; LL.M. 1953, University of California, Berkeley.

1. "Wo kein Klaeger, ist kein Richter," a German folk maxim.

2. See the new formulation in ABA COMm. ON CORp. Laws, Model Bus. Corp. ACt $\S 35$ (1974 Revision).

3. The right of a corporate officer to initiate litigation is a separate matter of corporate agency law; it typically does not extend to allow the major actions, particularly those attacking other corporate actors, that are the focus of this discussion. See generally Goebel, The Authority of the President Over Corporate Litigation: A Study in Inherent Agency, 37 Sr. JoHn's L. Rev. 29 (1962).

4. See Jones, An Empirical Examination of the Incidence of Shareholder Derivative and Class Action Law Suits, 1971-1978, 60 B.U. L. Rev. 306 (1980).

5. "Denuand on directors" is used herein as a shorthand phrase encompassing all postures in which a demand on directors may be involved, e.g., whether a plaintiff's failure to make a demand on the directors to sue will result in dismissal, as well as whether the rejection of demand by the directors will terminate the suit.

6. For fuller discussion of the prerequisites to derivative litigation, see $R$. JENNINOS \& $R$. BuXbaum, Corporations-CASES AND MATERIALS 628-83 (5th ed. 1979). 
posed of the action were incorrectly decided because such a result undermines the letter and spirit of apphicable conflict-of-interests statutes. Standards are then proposed to guide courts in deciding when a refusal to sue should terminate a derivative suit.

Rule 23.1 of the Federal Rules of Civil Procedure and similar state statutory or common law rules have created, in probably all jurisdictions, a substantive requireinent that plaintiffs seeking to initiate derivative actions first either demand of the company's board of directors that it commence the proposed litigation as a direct corporate action, or plead and denonstrate why such a demand was not necessary. Until recently this was little more than a formal requirement. If the underlying corporate complaint alleged inipermissible behavior-self-dealing or grossly imprudent acts-by even a few (let alone a nnajority, or all) of the current meinbers of the board, the demand was excused on the basis that it would be futile to expect "the board" to sue "itself" or solne of its members. ${ }^{7}$

Recently the demand requirement has been promoted to a inore important role in several jurisdictions. The details of this evolution have been commented upon extensively. ${ }^{8}$ For my purposes it is sufficient to note that its most important practical consequence has been to allow a small minority of board members to block derivative actions proposed to be brought against a current sitting majority of that board. ${ }^{9}$ Depending upon one's underlying view of derivative hitigation, this tentative development can be praised or condemned on the merits. The following partial condemnation is limited to an issue that has been overlooked by courts and commentators mvolved in this debate, an issue particularly relevant to the mentioned minority-approval situation.

When the challenged conduct involves self-dealing transactions between directors and their corporation-and that remains the important situation in derivative litigation ${ }^{10}$-statutory or analogous common law rules are involved and inust be considered. ${ }^{11}$ The cases which

7. E.g., Smith v. Spaulding, 354 U.S. 91 (1957); Elfenbein v. Gulf Western Indus., Inc., 454 F. Supp. 6 (S.D.N.Y.), affd, 590 F.2d 445 (2d Cir. 1978); Papilsky v. Berndt, 59 F.R.D. 95 (S.D.N.Y. 1973), appeal dismissed, 503 F.2d 554 (2d Cir.), cert. denied, 419 U.S. 1048 (1974).

8. See Dent, The Power of Directors to Terminate Shareholder Litigation: The Death of the Derivative Suit?, 75 Nw. U.L. REv. 96 (1980); Note, 1980 UTAH L. REv. 601; Note, The Business Judgment Rule in Derivative Suits Against Directors, 65 CORN. L. Rev. 600 (1980); Hinsey, Maldonado (NY) v. Maldonado (DE): Which Prevails?, Vol. IIl, Legal Times of Wash., Aug. 16, 1980, at 18; Black \& Sinith, Business Judgment, 13 Rev. SEC. REg. 935 (Apr. 23, 1980). From a business perspective, see Estes, Corporate Governance in the Courts, 58 HARV. Bus. REv. 50 (1980).

9. The extreme in delegations to small minorities of boards is well illustrated by Gall v. Exxon Corp., 418 F. Supp. 508 (S.D.N.Y. 1976) (delegation to 3 of 16 directors).

10. See Jones, supra note 4.

11. For a listing and analysis of these conflict-of-interests statutes, see Bulbuha \& Pinto, Statutory Responses to Interested Directors' Transactions: A Watering Down of Fiduciary Standards?, 53 Notre Dame L. Rev. 201 (1977). The role of common law rules, including their 
require a demand on directors and those which block further action if the demand is rejected rest on two justifications, one substantive, one technical. Substantively they rest on the Burks v. Lasker ${ }^{12}$ dicta that directors can be trusted fairly and impartially to scrutinize the conduct of their implicated fellow directors, and thus to respond appropriately to the demand. Technically they rest on a purported distinction between the authorization of a transaction and the decision not to proceed against even a regretted transaction.

Both justifications, however, must square with any relevant statutory or common law conflict-of-interests rules, a complication which has not been acknowledged or addressed by courts choosing to enforce the demand requirement. ${ }^{13}$ The newer statutory and common law rules governing potential conflict of interests created when directors are engaged im transactions with their corporation are curative rules. They relax earlier, more stringent sanctions against such transactions, sanctions that permitted the avoidance of the transactions without concern for their fairness and utility to the corporation, or that permitted avoidance unless a majority of the board of directors theinselves were disinterested. ${ }^{14}$ The new rules relax the avoidance sanction, however, under strict limiting conditions. Only if these are honored is it possible for less than a majority of the board of directors effectively to adopt or to ratify such transactions.

Simplified for present purposes, the curative rules prescribe some level of conduct ("fair," "just and reasonable") understood to be stricter than the business judgment standard applied to arm's-length transactions. ${ }^{15}$ As to some, and perhaps all, of the formal curative decisionmaking procedures permitted by the new rules, the burden of proving compliance with this higher standard may be imposed upon the proponents of the transactions. ${ }^{16}$ These curative procedures are threefold: either those dismterested members of the board having full

continuing importance for events not clearly covered by statute, is discussed in Note, The Status of the Fairness Test Under Section 713 of the New York Business Corporation Law, 76 ColuM. L. REv. 1156 (1976).

12. 441 U.S. $471,481-82,485$ (1979).

13. Statutory and common law considerations have been addressed in a general way in Maldonado v. Flynn, 413 A.2d 1251, 1259-60, 1263 (Del. Ch. 1980) (appeal pending). See also Abella v. Universal Leaf Tobacco Co., [1979-1980 Transfer Binder] SEC. REO. REP. (CCH) \ 97,649 (E.D. Va., filed Aug. 6, 1980).

14. See Marsh, Are Directors Trustees?, 22 Bus. LAw, 35 (1966); authorities cited note 11 supra.

15. While not necessarily based upon the statutes, the following opinions illuminate this distinction: Cohen v. Ayers, 596 F.2d 733 (7th Cir. 1979); Sinclair Oil Corp. v. Levien, 280 A.2d 717 (Del. Sup. Ct. 1971); Schreiber v. Bryan, 396 A.2d 512 (Del. Ch. 1978); $c f$ also the reorganization "fairness" cases exemplified by Singer v. Magnavox Co., 380 A.2d 969 (Del. Sup. Ct. 1977).

16. The statutory effort to eliminate the faimess requirement in the event of shareholder ratification, for example, has not worked. See, e.g., Remillard Brick Co. v. Remillard-Dandini 
knowledge of their fellow directors' self-interest inay approve the transaction; or the shareholders may approve it; or the transaction may be proved to be fair or just.

What is important about the combination of standard and procedure is that the first two of these three methods are prospective im nature. What is granted to a minority ${ }^{17}$ of the board of directors, ${ }^{18}$ in other words, is only the right to enter into a contract or transaction, not the right to ratify a fait accoinpli which, though it may in theory be one they can repudiate, presents entirely different and greater constraints upon the decisionmaker than does a prospective decision. This limiting condition is to be contrasted with the third curative approach, the proof of fairness. This by definition is retrospective: a decision not properly made initially can yet be rehabilitated, but im an adversary context, before a judge and jury, not by one or some members of the board making an ex parte decision.

The interplay between substantive standards and standards for judicial review $\mathrm{m}$ the context of the derivative action may be illustrated by analysis of a typical statute, section 144 of the Delawarc General Corporation Law. No transaction is void or voidable solely because of a conflict of imterests if, material facts known, "the board . . . m good faith authorizes the . . transaction by the affirmative votes of a majority of the disinterested directors, even though the disinterested directors be less than a quorum . ..."19 In contrast, section 144(a)(3) cures voidable transactions if they were fair as of the time they were authorized or ratified by the board. ${ }^{20}$ This procedure contemplates a later, post-authorization or ratification test, one specifically charged to avoid the use of hindsight.

The New York statute, section 713 of the Business Corporation Law, reveals the same distinction. Approval of a pending, not-yet-effected transaction is authorized by section 713(a)(1) under similar disclosure conditions, "by a vote sufficient for such purpose without counting the vote of such interested director or, if the votes of the dismterested directors are imsufficient to constitute an act of the board . . ., by unanimous vote of the disinterested directors . . .."21 If, however, there is no prospective approval, or no approval that is adequate, subdivision (b) provides for avoidance of the transaction "unless the [pro-

Co., 109 Cal. App. 2d 405, 241 P.2d 66 (1st Dist. 1955); authorities reviewed in R. Jennings \& R. BuXBaum, supra note 6, at 459-60.

17. Sometimes a minority of one arguably suffices. See, e.g., N.Y. Bus. CORP. LAW § 713(a)(1) (McKinney 1971 \& 1979 Supp.).

18. The point holds true of shareholder ratification as well.

19. DeL. CODE ANN. tit. VIII, § 144(a)(1) (1975) (emphasis added).

20. Id. \& 144(a)(3) (1975).

21. N.Y. Bus. CoRP. LAW \& 713(a)(1) (McKinney 1971 \& 1979 Supp.). 
ponent] shall establish affirmatively that the contract or transaction was fair and reasonable as to the corporation at the time it was approved .22 Again, the statute contemplates a retrospective decision, witlout the use of hindsight, by a decisionmaker outside the corporate decisional structure.

The third major statutory form of the curative statute, section 310 of the California Corporations Code, also requires the transaction to meet a fairness standard and, additionally, requires an autonomous verification. Section 310(a) makes transactions nonvoidable despite the material financial self-interest of one or more directors if, after appropriate disclosure, "(2) . . . the board . . . authorizes, approves or ratifies the contract or transaction in good faith by a [sufficient independent vote] and the contract or transaction is just and reasonable as to the corporation as of the time it is authorized, approved or ratified .23 Section 310(a)(3) provides the typical alternate curative mode as to transactions not so approved, vahdating the transaction or contract: if "the person asserting [its] vahidity . . . sustams the burden of proving that [it] was just and reasonable as to the corporation at the time it was authorized, approved or ratified." 24

The 310(a)(2) "fairness" requirement, despite the fact that it appears in combination with a requirement of approval by "imdependent directors" rather than only separately as an independent curative option, does not differentiate the California statute fundamentally from those of other jurisdictions; indeed, it confirms the conclusion that for retrospective curative efforts an independent judge is required im case of attack. Marsh points out that the relevance of the separate fairness proviso lies in the difference between the burden of proof of fairness required in the case of challenge to a director-approved transaction as contrasted with a challenged transaction defended on the ground of "fairness" alone. ${ }^{25}$ Even a transaction prospectively approved by an appropriate number of independent directors is subject to challenge; im that case, however, the complainant must carry the burden of proving that it was not "just and reasonable" at the time of its approval. The

22. Id. § 713(b). See Lewis v. S.L. \& E., Inc., 629 F.2d 764 (2d Cir. 1980).

23. CAL. CORP. CODE \& 310(a) (West 1977 \& 1980 Supp.).

24. Id. $\$ 310(\mathrm{a})(3)$. The addition of "ratification" to the board's right of "authorization" and "approval" of course has no bearing on the present problem. It completes a more detailed listing of the various modes by which decisions may be effected. Some may be entered into by subordmate decisionmakers without adequate authority and need to be adopted or ratified by the appropriate plenary management body-hence ratification. Occasionally this mode may legitimate a transaction within the subordimate officer's authority but tainted by a conflict of interests at that level. That too is subject to the text discussion of the "doubled" fairness screen imposed upon board action by the statute.

25. $16 \mathrm{H}$. Marsh, California Corporation law and Practice $\S 10.8$, at 583 (Ist ed. 1977). 
determination of that challenge, however, also takes place before an independent arbiter - the judge-in the usual adversary context. A fortiori, then, a challenge to a transaction entered into without prior director approval, as to which the proponents are to carry the burden of proving the transaction just and reasonable, can take place only before a court.

In short, the price which the modern validating rules exact for their rejection of automatic avoidance of self-interested transactions is either prospective approval under specified conditions or retrospective approval under adversary conditions and by an autonomous decisionmaker. This distinction intuitively makes sense. One need not totally accept Judge Friendly's comments ${ }^{26}$ about the difficult position of nominally independent directors who are expected cooly to judge their fellow directors' behavior to embrace the narrower proposition implicit in these statutes: that however difficult it may be to restrain fellow directors from a proposed course of conduct, it is excessively difficult to repudiate a transaction already effected by one's fellow directors, thereby subjecting them, among other things, to financial sanctions. Indeed, this is so clear to the courts that in the leading case of Bennett $v$. Propp $^{27}$ it led the Delaware Supreme Court to absolve those directors who reluctantly acquiesced in a fait accompli from liability to the corporation, although such liability was visited upon the directors who had initiated the transaction. ${ }^{28}$

Whether a transaction initially was properly approved by the requisite number of independent directors, and thus cured of any "taint," often is a difficult question that is not answered uniformly ainong the jurisdictions. In some jurisdictions a majority of the board inay be necessary; in others only enough to constitute a quoruin (typically onethird of the board); in others perhaps only a number sufficient to constitute a majority of the relevant quoruin; im others only all or a majority of the independent directors though all together are less than a quorum; and finally in yet others perhaps only the sole independent director if there be only one. ${ }^{29}$ In some of the cases that adopt the new, still debatable position that a nominally independent director's refusal to sue precludes a derivative suit, the original transaction was in fact authorized by a sufficient number of independent directors to ineet the

26. Lasker v. Burks, 567 F.2d 1208, 1212 (2d. Cir. 1978), rev'd on other grounds, 441 U.S. 471 (1979).

27. 41 Del. Ch. 14, 187 A.2d 405 (Sup. Ct. 1962).

28. Buxbaum, 'Maldonado' Cases Could Lock Shareholders' Door, Vol. III, Legal Times of Wash., Oct. 13, 1980, at 26.

29. For a review of the entire gamut of possibilities see Marsh, supra note 14, at $46-48$ (1966). For recent examples of the variations the newer statutes may generate, see R. JENNINGS \& R. BUXBAUM, supra note 6, at 459. 
requirements of the statute or analogous common law rule. ${ }^{30}$ In some, however, there was not a sufficient number or, when there was, the authorizing process simply was not utilized. ${ }^{31}$

In this latter situation, assuming that the statutory analysis presented here is correct, the transaction has not been cured of its selfdealing tamt, and at best can be cured only by submitting it to retrospective judicial scrutiny. If this is to be thwarted by a dispositive refusal to sue upon demand, it must be through the resurrection of the old and discredited distimction between approval of a transaction and a later unwillingness to go to court for redress of harm done the corporation by reason of the transaction. ${ }^{32}$ That distinction, in the procedural context hcre at issue, is neither logically sound nor sound as a matter of policy. Moreover, it was repudiated long ago by most American jurisdictions. ${ }^{33}$

Known as the Massachusetts rule after S. Solomont \& Sons Trust, Inc. v. New England Theatres Operating Corp. ${ }^{34}$ the distinction was there developed to force plaintiffs in a pending derivative action, who were not required to make what clearly would have been a futile demand on the directors, nevertheless to make a deinand on shareholders who were disinterested and therefore might appropriately decide on the proper corporate course of action. The court's effort to overcoine the undisputed substantive law proposition that fraudulent managerial belavior could not be ratified by less than all of the shareholders consisted of the following statement: "We shall not rest our decision upon the power to ratify. The question whether it is good judgment to sue is quite apart from the question of ratification. This is a distimction of

30. That was the case in Burks v. Lasker, 441 U.S. 471 (1979) (Delaware law), Abbey v. Control Data Corp., 603 F.2d 724 (8th Cir. 1979), cert. denied, 444 U.S. 1017 (1980) (Delaware law), and Auerbach v. Bennett, 47 N.Y.2d 619, 419 N.Y.S.2d 920, 393 N.E.2d 994 (1979) (New York law).

31. Thus the number was inadequate in Lewis v. Anderson, 615 F.2d 778 (9th Cir. 1979), a diversity case purporting to apply, but, if the analysis in text is correct, in reality ignoring the California statutory requirement that validation of a challenged action requires the approval of a number of disinterested directors large enough to constitute a normal quorum. See note 29 supra.

The reliance in both Lewis and Abbey on a statutorily authorized delegation of management power to committees of the board as a way of finessing the requirement of an adequate number of disinterested dircctors seems to be a particularly permicious case of bootstrapping. I therefore classify such cases as belonging to the group in which the substantive requirements of the statutory curative mode were not inet.

32. See particularly Hinsey, supra note 7. See also Cramer v. General Tel. \& Elec. Corp., 582 F.2d 259 (3d Cir. 1978), cert. denied, 439 U.S. 1129 (1979).

33. The prevalent rule is stated in Mayer v. Adams, 37 Del. Ch. 298, 311-12, 141 A.2d 458, 462 (Sup. Ct. 1958).

34. 326 Mass. 99,93 N.E.2d 241 (1950). See also Bell v. Amold, 175 Colo. 277, 487 P.2d 545 (1971) (adopting the Massachusetts rule); Escoett v. Aldecress Country Club, 16 N.J. 438, 109 A.2d 277 (1954). 
substance and not of form."35

A major argument against this view, ${ }^{36}$ which applies with equal force to directors' as well as to shareholders' efforts to reject a demand to sue, involves a basic principle of substantive law: "It seems clear .. that the substantive law which holds certain wrongs to be mcapable of ratification by a majority of the shareholders manifests a policy that these wrongs inay be redressed by a minority shareholder after he has exhausted his intracorporate remedies."37 To accept the nominally procedural Massachusetts distmction would be to repudiate the general substantive rule by indirection. ${ }^{38}$

What courts resting on this specious distinction wish to achieve is understandable, and in some cases worth accommodating, but not in this way. Their goal is to save corporations froin futile but expensive litigation; abuse of the deinand requirement, however, overshoots that goal. This can be illuminated by examining those cases in which the original transaction in fact was authorized by a number of directors sufficient to meet the applicable substantive conflict-of-interests curative rules. First of all, a complaint charging that the transaction was "unfair," yet admittmg that its authorization fit the curative requirements (or at least not rebutting an answer so pleading) is demurrable. There simply is no cause of action on that ground. The use of a strimgent demand-on-directors requirement in this situation is no more than the functional equivalent of the grant of a demurrer. ${ }^{39}$ Therefore a court sliould enforce such a requireinent.

A different problem arises, however, if the complainant now seeks to escape this bar by suing the independent directors as well; either those still in office who, sufficient in number to meet the curative statute's conditions, authorized the transaction originally, or those now in office wlio with knowledge of the transaction nevertheless refuse to undo its consequences. Consider the first of these two possibilities, that of suing both the originally interested and disinterested directors, all of

35. 326 Mass. at $111 ; 93$ N.E.2d at 247.

36. A second argument, more relevant to shareholder than to director ratification, concerns the problem of bow to assure adequate communication of relevant evidence bearing on the transaction to the shareholders, particularly via the proxy solicitation mechanism. See Mayer v. Adams, 37 Del. Ch. 298, 141 A.2d 458 (Sup. Ct. 1958); Leavell, The Shareholders as Judges of Alleged Wrongs by Directors, 35 TuL. L. REV. 331, 354-55 (1961).

37. N. Lattin, R. Jennings \& R. Buxbaum, Corporations-Cases and Materials 82122 (4th ed. 1968).

38. See Continental Securities Co. v. Belmont, 206 N.Y. 7, 99 N.E. 138 (1912); Mayer v. Adams, 37 Del. Ch. 298, 141 A.2d 458 (Sup. Ct. 1958).

39. Because of the phrasing of FED. R. Crv. P. 23.1, the pleadings as to the demand issue require greater specificity than do normal pleadings; see the full discussion of this distinction in $I n$ re Kauffman Mutual Fund Actions, 479 F.2d 257 (1st Cir.), cert. denied, 414 U.S. 857 (1973); cf. Heit v. Baird, 567 F.2d 1157 (1st Cir. 1977); Vernars v. Young, 539 F.2d 966 (3d Cir. 1976). 
whom continue in office. ${ }^{40}$ The proper allegation in that case is "waste of assets"; i.e., actionable imprudence in authorizing the transaction. This, typically, is a difficult pleading to sustain. The effort of some courts to avoid a potentially futile yet expensive proceeding by blocking its continuation through the demand-on-directors requirement is in many cases quite understandable. ${ }^{41}$

Yet on this pleading, demand would be futile and thus should be excused, ${ }^{42}$ since the directors being sued, although only for actionable imprudence, are the ones who would control the response to the demand. In this situation trial-or at least embarking on the road to trial-is required, since to impose the absolute bar of the demand requirement is illegitimately to create a demurrer remedy to a fact dispute. ${ }^{43}$ Why of all defendants only corporate directors should be spared the paim of responding to properly pleaded but in the proof eventually deficient complaints is not apparent. That the innocent corporation and its shareholders thereby are subjected to inconvenience and expense seems irrelevant. Third-party complaints against corporate agents and employees are not similarly disfavored. Nor is the distinction between a third party's and an owner's complaint against an agent relevant. So long as the substantive law of actionable neghigence permits an owner to sue an agent, and so long as in a joint-owner case it excuses the agent's behavior only upon the unanimous consent of all owners, ${ }^{44}$ then such a coinplaint deserves the saine kind of procedural regularity as one that charges the bishop of Boston with bastardy.

Only in the second situation,-when new directors now in office refuse to undo an earlier transaction, itself properly authorized under curative rules and therefore challengeable only as a waste of assets rather than as "unfair"--does the demand on directors play its full role. ${ }^{45}$ Only the earlier ex-directors are being sued: for actionable imprudence in the case of the authorizing, if not also of the benefitted group. The new directors cannot be implicated in the original allegedly imprudent decision and under this assuinption have not been sued. In this case they can respond properly to a demand, and a demand on them should be required. ${ }^{46}$

40. See, e.g., Barr v. Wackman, 36 N.Y.2d 371, 368 N.Y.S.2d 497, 329 N.E.2d 180 (1975).

41. See In re Kaufiman Mutual Fund Actions, 479 F.2d at 267.

42. Even if only the disinterested directors respond to the detnand, it should be excused.

43. Berger v. General Umited Group, 268 N.w.2d 630 (lowa 1978).

44. See Continental Securities Co. v. Belmont, 206 N.Y. 7, 99 N.E. 138, 142 (1912); cf. Maldonado v. Flynn, 413 A.2d $1251^{\circ}$ (Del. Ch. 1980) (appeal pending).

45. See the factual setting in Galef v. Alexander, 615 F.2d 51 (2d Cir. 1980); cf. In re Kauffman Mutual Fund Actions, 479 F.2d 257 (1st Cir.), cert. denied, 414 U.S. 857 (1973); Findlay v. Garrett, 109 Cal. App. 2d 166, 240 P.2d 421 (2d Dist. 1952).

46. It is a separate question whether rejection of a demand autonatically bars the proposed action. Compare Swanson v. Traer, 249 F.2d 854 (7th Cir. 1957) (following remand of same, 354 
Even then the logical consequence should be drawn. The disappointed claimant now may sue these current directors, derivatively, on the ground that their present refusal to pursue the earlier cause of action is so egregious as itself to amount to actionable imprudence. ${ }^{47}$ That too is a well-pleaded cause of action, not subject to the masked demurrer of the demand requirement. If a court wishes to expedite the resolution of well-pleaded complaints that nevertheless stand little chance of success it can already in the first action examine the new directors' refusal to respond to the deinand inade upon thein. If their refusal seems indefensible, the court has the discretion to permit the suit to proceed against the old director-defendants at once. This is the old but sound rule of Groel v. United Electric Co. of New Jersey, ${ }^{48}$ and finds its inodern form in the rule of some courts that would require demand but would not automatically bar the derivative action simply because the demand was rejected. ${ }^{49}$ The other side of the coin, of course, is that if the court finds the rejection rational enough not to constitute an actionable waste of assets, that second suit thereby is precluded in advance. ${ }^{50}$

This perception, which recognizes the demand-on-directors requirement as a species of demurrer, suitable only where demurrers are suitable, is both proper and mevitable once one recognizes the distinction between the substantive law governing the various aspects of corporate transactions and the procedure for launching complaints based on that law.

A final and separate question is suggested by the Groel $^{S_{1}}$ approach, and its modern variation in the recent Second Circuit decision in Galef $v$. Alexander. ${ }^{52}$ Under this approach the plaintiff's case is telescoped imsofar as the court inakes an expedited pretrial finding of fact as to the rationality of the independent new directors' refusal to sue, and in effect grants the director-defendants suminary judgment if that refusal is found rational. Whether this much compression of a plam-

U.S. 114 (1957)) with Galef v. Alexander, 625 F.2d 51 (2d Cir. 1980). To that issue the immediately following text pertains.

47. See R. Jennings \& R. Buxbaum, supra note 6, at 662.

48. 70 N.J. Eq. 616,61 A. 1061 (Ch. 1905).

49. See note 42 supra.

50. Note, however, that the review would not be under as deferential a standard as that applicable to original charges of actionable imprudence by a disinterested board, but would and should require a decent level of explanation as to why a prima facie appropriate effort to recoup a corporate asset nevertheless was not appropriate. This is clearly articulated in Tannenbaun v. Zeller, 552 F.2d 402, 418 (2d Cir.), cert. denied, 434 U.S. 934 (1977); see Note, Mutual Fund Independent Directors: Putting a Leash on the Watchdogs, 47 FordHAM L. REv. 568, 581 (1979), and, for a similar approach, Note, 1980 UTAH L. REv. 601. This is already recognized not only in Groel, but also in Findlay v. Garrett, 109 Cal. App. 2d 166, 240 P.2d 421 (2d Dist. 1952).

51. See text accoinpanying notes 48-49 supra.

52. See note 45 and accompanying text supra. 
tiff's right to a full trial, and particularly to full pretrial discovery proceedings, is appropriate is a question of policy beyond the scope of this discussion.

One aspect of the problem of the desirability of such compression, however, bears on my focus on the role of the substantive law of loyalty in understanding derivative suit requirements-the fact that often the plaintiffs are only nominal parties in interest.

In one important sense, derivative suits are a subset of contingent fee litigation. It is often claimed that such litigation is mappropriately expensive because the risk propensity of plaintiff's attorneys, both as to their time and as to their potentially unrecoupable nonetary expenditures, bears no relation to the "true" value of the case. ${ }^{53}$ By subjecting defendants to comparable expenses incommensurate with an objective perception of the lawsuit's value, plaimtiffs therefore may force settlements in which defendants' saved future expenditures, transferred to the plaintiffs' side, become the principal measure of case value.

This nuisance variation of the old and overwhelmingly discredited strike suit characterization ${ }^{54}$ lias been challenged both on general theoretical $^{55}$ and -at least as to derivative suits-on empirical grounds. ${ }^{56}$ Moreover, this approach overlooks one important characteristic peculiar to the derivative suit variant of contimgent fee litigation-the power of the directors to settle the action unilaterally. ${ }^{57}$

So long as the independent directors in office suffice to take pro-

53. See the discussion in Comment, The Demand and Standing Requirements in Stockholder Derivative Actions, 44 U. CHI. L. REV. 168 (1976).

54. See the conflict between the studies and analyses made by Wood and Hornstein, and the analysis of that conflict, in Dykstra, The Revival of the Derivative Suit, 116 U. PA. L. REv. 74, 76, 88 (1967). See also the discussion in R. Jennings \& R. BuXBAum, supra note 6, at 677-83.

55. See Posner, An Economic Approach to Legal Procedure and Judicial Administration, $2 \mathrm{~J}$. LEG. Stud. 399, 433 (1973); $f$. Dam, Class Actions: Efficiency, Compensation, Detcrence and Confict of Interest, 4 J. LEG. STUD. 47 (1975).

A separate problein concerns the inherent conflict of interests between the attorney representing the derivative plaintiff and the corporate client. See generally Scliwartz \& Mitchcll, An Economic Analysis of the Contingent Fee in Personal Injury Litigation, 22 STAN. L. Rev. 1125 (1970), and specifically as to class actions Rosenfield, An Empirical Test of Class Action Settlement, $5 \mathrm{~J}$. LEG. STUD. 113 (1976). That, however, is a problein coucerning the optimal efficiency of contingent fee litigation settleinent, but even an inadcquate settlement is more efficient than no action on a meritorious complaint.

Finally, it is important to distinguish the argument that the marketplace for shares provides the most efficient mechanism for policing conflict-of-imterests situations. That is an argument against any given snbstantive conflict-of-interests rule, not against the derivative suit as a means of enforcing that given norm. For a recent, wide-ranging presentation of that argument, see Hetherington, When the Sleeper Wakes: Reflection on Corporate Govemance and Shareholder Rights, 8 HofstRA L. REv. 183, $195-99$ (1979).

56. See Jones, An Empirical Examination of the Resolution of Shareholder Derivative and Class Action Lawsuits, 60 B.U. L. REV. 542 (1980).

57. See Wolf v. Barkes, 348 F.2d 994 (2d Cir. 1965). 
spective action under the described substantive rules ${ }^{58}$ (and that by definition is the case in this discussion of expedited procedures), they may settle the underlying action with the implicated defendant-directors without court approval, thus undercutting the ongoing action. This step converts a charge that the imprudence of the independent directors and, if applicable, the self-dealing of the implicated ones caused a corporate loss of $\$ X$, to one that the imprudence of the independent directors in causing the corporation to settle its claim against the implicated directors for only $\$ Y$ caused a corporate loss of $\$(X-Y)$. This is not a nice step to take and in fact seeins infrequent in practice, ${ }^{59}$ but it does provide a suitable check against the often imaginary horrible of plaintiffs' attorneys abusing their bargaining position to the poimt of refusing all reasonable settlement offers. A reasonable settlement under such circumstances, instigated by the appropriate number of independent directors, undoubtedly would prevail agamst the plaintiff's second-ditch argument that, although independently decided on, the settlement decision was actionably imprudent.

With this concession to the often asserted but seldom proved argument that much derivative hitigation is illegitimate and thus deserves forestalling, the deinonstrated need to fit derivative suit procedures, includimg the demand on directors, within the governing substantive fiduciary rules can be confirmed as sound policy. 1980).

58. This is the critical issue in Clark v. Lomas \& Nettleton Fin. Corp., 625 F.2d 49 (5th Cir.

59. See the treatment in Herbst v. ITT, 72 F.R.D. 85 (D. Conn. 1976). 